\title{
Photosynthetic responses of four tropical tree species grown under gap and understorey conditions in a semi-deciduous forest
}

\author{
GUSTAVO M. SOUZA ${ }^{1,4}$, AGNALDO M. SATO ${ }^{1}$, RAFAEL V. RIBEIRO² and \\ CARLOS HENRIQUE B. A. PRADO ${ }^{3}$
}

(received: January 17, 2008; accepted: September 16, 2010)

\begin{abstract}
Photosynthetic responses of four tropical tree species grown under gap and understorey conditions in a semi-deciduous forest). Leaf $\mathrm{CO}_{2}$ assimilation $(A)$ as a function of photosynthetic photon flux density $(Q)$ or intercellular $\mathrm{CO}_{2}$ concentration $(\mathrm{Ci})$ and chlorophyll fluorescence measurements were carried out on four tropical woody species growing in forest gap and understorey (Bauhinia forficata Link. and Guazuma ulmifolia Lam. as pioneers, and Hymenaea courbaril L. and Esenbeckia leiocarpa Engl. as non-pioneers). Chlorophyll fluorescence indicated similar acclimation capacities of photochemical apparatus to contrasting light environments irrespective to plant species. Maximum $\mathrm{CO}_{2}$ assimilation and quantum yield derived from $A / Q$ curves indicated higher photosynthetic capacity in pioneer than in non-pioneer species in forest gap. However, the differences among species did not show a straightforward relation with their successional status regarding data derived from $A / Q$ curves under understorey conditions. Both successional groups are able to sustain positive carbon balance under contrasting natural light availabilities, modifying photochemical and biochemical photosynthetic traits with similar phenotypic plasticity capacity.
\end{abstract}

Key words - acclimation, chlorophyll fluorescence, forest succession, leaf gas exchange, photosynthetic response curves

RESUMO - (Respostas fotossintéticas de quatro espécies tropicais arbóreas crescidas sob condições de clareira e de sub-bosque em uma floresta semi-decídua). A assimilação de $\mathrm{CO}_{2}$ (A) em função da densidade de fluxo de fótons fotossintéticos $(Q)$ ou da concentração intercelular de $\mathrm{CO}_{2}(\mathrm{Ci})$, e medidas de fluorescência da clorofila foram realizadas em quatro espécies tropicais arbóreas em uma clareira e um sub-bosque (Bauhinia forficata Link. e Guazuma ulmifolia Lam. como espécies pioneiras, e Hymenaea courbaril L. e Esenbeckia leiocarpa Engl. como espécies não pioneiras). Os dados de fluorescência da clorofila indicaram que ambos os grupos mostraram capacidade similar de aclimatação do aparato fotoquímico independente do ambiente luminoso. A assimilação máxima de $\mathrm{CO}_{2}$ e a eficiência quântica derivadas das curvas $A / Q$ indicaram maior capacidade fotossintéticas das espécies pioneiras do que as não-pioneiras na clareira. Entretanto, sob condições de sub-bosque, as diferenças observadas em relação às curvas $A / Q$ não mostraram uma relação direta com o grupo funcional das espécies. Ambos os grupos da sucessão foram capazes de manter um balanço de carbono positivo sob disponibilidades de luz contrastantes, modificando as características fotoquímicas e bioquímicas da fotossíntese com capacidade de plasticidade fenotípica similar.

Palavras-chave - aclimatação, curvas de resposta fotossintética, florescência da clorofila, trocas gasosas foliares, sucessão florestal

\section{Introduction}

Tropical forest environments often show a wide range of light availability either in spatial or temporal scales. Photosynthetic photon flux densities $(Q)$ varied from $25 \mu \mathrm{mol} \mathrm{m}^{-2} \mathrm{~s}^{-1}$ in early morning to $2,300 \mu \mathrm{mol} \mathrm{m} \mathrm{m}^{-2} \mathrm{~s}^{-1}$ around midday in gap conditions while low and diffuse irradiance punctuated by sunflecks

1. Universidade do Oeste Paulista, Laboratório de Ecofisiologia Vegetal, Rodovia Raposo Tavares km 572, 19067-175 Presidente Prudente, SP, Brazil.

2. Instituto Agronômico, Centro de Pesquisa e Desenvolvimento em Ecofisiologia e Biofísica, Caixa Postal 28, 13001-970 Campinas, SP, Brazil.

3. Universidade Federal de São Carlos, Departamento de Botânica, 13565-905 São Carlos, SP, Brazil.

4. Corresponding author: gustavo@unoeste.br is found in understorey (Bazzaz \& Picket 1980, Chazdon et al. 1996). Therefore, tropical tree species often experience substantial light variation during their life span in forest environments.

In general, tree species may be separated in two successional groups according to spatial and temporal plant distribution in tropical forests: i) early successional species, which are light demanding and named pioneer; ii) late successional species, which are shade tolerant and named late secondary species. These functional groups help to predict the plant community response to environmental changes without requiring detailed information from each species (Lavorel et al. 1997, Reich et al. 2003). Group of species can be defined by life history, life form, taxonomy, physiological traits or some combination of these characteristics (Tilman 1997, Hooper 1998). The common sense suggests that 
a functional group differs consistently on average from another group with respect to a set of target traits (Reich et al. 2003). Functional group is especially attractive in tropical conditions reducing the number of species to reveal general processes or patterns in ecosystems (Ellis et al. 2000).

Pioneer species exhibit marked reduction of photosynthetic capacity when growing under low light availability as well as high responsiveness to increasing light intensity (Chazdon et al. 1996, Strauss-Debenedetti \& Bazzaz 1996). On the other hand, many species grown in forest understorey show little or no potential to increase maximum photosynthetic rates in response to increasing light availability (Strauss-Debenedetti \& Bazzaz 1996, Ribeiro et al. 2005), which suggests high autonomy in relation to environmental light fluctuations (Souza et al. 2005).

Comparisons between low- and high-light specialists suggest that there are different capacities of light acclimation (Strauss-Debenedetti \& Bazzaz 1996). Classical grouping in early and late successional is based essentially on sun/shade adapted dichotomy, through which it is possible to identify a continuum of photosynthetic traits between successional groups of trees. Early successional species would have higher physiological plasticity in relation to late successional species (Bazzaz 1979). However, some shade-adapted species can exhibit substantial photosynthetic plasticity across different light levels (Ellis et al. 2000). Late successional species eventually reach upper forest stratum that characterizes a great potential for photosynthetic acclimation (Pearcy 1987). There is increasing evidence that light-demanding and shade-tolerant species are capable of adjustments in photosynthetic apparatus (Turnbull 1991, Popma et al. 1992). However, leaves of shade-tolerant species often have lower net photosynthesis (Koike 1988, Raaimakers et al. 1995) and leaf mass per area (Popma et al. 1992) than light-demanding species, regardless of light environment.

In general, the capacity of a given tropical tree species to render different phenotypes (plasticity) is possible after long-term exposure to a light environment, which enables plant acclimation. In fact, plant metabolism undergoes acclimation after a prolonged exposure to different growth conditions (Stitt \& Hurry 2002, Atkin \& Tjoelker 2003, Flexas et al. 2006) that may affect photosynthetic and respiratory rates. The objective of the present study was to test the hypothesis that pioneer and non-pioneer tropical tree species are able to adjust their photosynthetic processes (photochemical and biochemical ones) in both forest gap and understorey for sustaining positive carbon balance in contrasting light environments. Moreover, considering that photosynthesis is dependent on plant nutritional status, the photosynthetic performance of pioneer species probably is related to a great capacity of nutrient uptake and use (Riddoch et al. 1991, Bazzaz 1996). Therefore, we may expect some variation in the interaction between photosynthetic performance and nutritional status when comparing species in contrasting environments such as forest gap and understorey. Classical pioneer and non-pioneer saplings were grown under natural conditions in forest gap and understorey for testing those hypotheses, evaluating leaf gas exchange, photochemistry, leaf nutritional status, and plant growth traits.

\section{Material and methods}

Experimental site, plant species and growth conditions - This study was carried out in a semi-deciduous seasonal forest with 5.5 ha located in Narandiba county, São Paulo, Brazil (2224' S; 51 $31^{\prime}$ 'W, $354 \mathrm{~m}$ a.s.1.). The gap size was $34.5 \mathrm{~m}^{2}$, corresponding to a small gap with canopy openness around $10 \%$. Small gap is far more frequent in tropical forest than large ones (Martins \& Rodrigues 2002). Soil samples were collected at $20 \mathrm{~cm}$ of depth for chemical analysis in both forest gap and understorey. The soil of the area is a ultisol type, and its nutritional status in forest gap and understorey were respectively: 0.3 and $1.1 \mathrm{mmol}_{\mathrm{C}} \mathrm{K}^{+} \mathrm{dm}^{-3} ; 1.0$ and $4.0 \mathrm{mmol}_{\mathrm{C}} \mathrm{Ca}^{+2} \mathrm{dm}^{-3} ; 1.0$ and $2.0 \mathrm{mmol}_{\mathrm{C}} \mathrm{Mg}^{+2} \mathrm{dm}^{-3} ; 9.6$

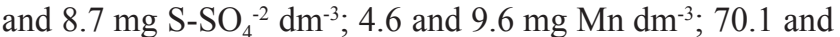
$87.5 \mathrm{mg} \mathrm{Fe} \mathrm{dm}^{-3}$; and $8.0 \mathrm{mg} \mathrm{P} \mathrm{dm}^{-3}$. The $\mathrm{pH}$ value (in $\mathrm{CaCl}_{2}$ ) of soil solution was 3.8 and 4.0 and the organic matter was 17 and $19 \mathrm{~g} \mathrm{dm}^{-3}$ for soil samples collected in forest gap and in understory respectively.

Four woody species from different successional groups were studied: Bauhinia forficata Link (Caesalpinioideae) and Guazuma ulmifolia Lam. (Sterculiaceae) are putative pioneer species, and Hymenaea courbaril L. (Caesalpinioideae) and Esenbeckia leiocarpa Engl. (Rutaceae) are considered late successional species (Lorenzi 1992). B. forficata and G. ulmifolia grow in secondary forests up to 9 and $16 \mathrm{~m}$ tall, respectively, being semi-deciduous and light demanding species. H. courbaril is a typical late secondary species growing up to $20 \mathrm{~m}$ tall with widespread distribution in semi-deciduous Brazilian forests. E. leiocarpa occurs in primary forests being shade tolerant with maximum height of $30 \mathrm{~m}$ and sensitive to high irradiance during initial development (Lorenzi 1992).

Pioneer (B. forficata and G. ulmifolia) and late successional (H. courbaril and E. leiocarpa) species were germinated and grown under nursery conditions under $50 \%$ of full sunlight. At planting date, pioneer and late successional species were 10-months-old, had $66 \pm 3$ (pioneers) and $53 \pm 2 \mathrm{~cm}$ (late successional) tall and with stem diameter around $8 \pm 2 \mathrm{~mm}$ (at $5.0 \mathrm{~cm}$ from soil surface) regardless of 
functional group. Ten saplings of each species were planted in forest gap and understorey with a minimum distance of 1.0 $\mathrm{m}$ from each other. Physiological measurements were taken six months after planting on fully expanded leaves developed in forest gap $(G)$ or understorey $(U)$. We considered that the growth of new cohort of leaves was an evidence of plant acclimation to each forest site.

Physiological evaluations - The measurements of physiological variables were taken during sunny days, with air temperature (Tair), photosynthetic photon flux density $(Q)$ and minimum relative humidity (RHmin) varying in forest gap $(G)$ and understory $(U)$ as follows: Tair $=20$ to $36^{\circ} \mathrm{C}$ in $G$ and 18 to $30^{\circ} \mathrm{C}$ in $U ; Q=1,600 \pm 200 \mu \mathrm{mol} \mathrm{m}{ }^{-2} \mathrm{~s}^{-1}$ in $G$ and $30 \pm 5 \mu \mathrm{mol} \mathrm{m}^{-2} \mathrm{~s}^{-1}$ in $U$; and RHmin $=25 \pm 3 \%$ in $G$ and $36 \pm 4 \%$ in $U$. Non-significant changes were observed in relation to gap openness or light conditions in each forest site during the period of evaluation. All physiological measurements were carried out when plants were not under water deficit, given by leaf water potential at pre-dawn around - 0.5 MPa measured with a pressure chamber (model PMS 1000, PMS Instruments, USA).

Chlorophyll fluorescence was evaluated with a portable fluorescence system model FMS 2 (Hansatech Instruments, UK) in mature (but not senescent) fully expanded leaves without signals of herbivory and free of moss or fungi. Measurements light using a modulating beam $\left(<0.05 \mu \mathrm{mol} \mathrm{m} \mathrm{m}^{-2} \mathrm{~s}^{-1}\right.$ with duration pulses of $\left.1.8 \mu \mathrm{sec}\right)$ and saturating pulses $\left(18,000 \mu \mathrm{mol} \mathrm{m} \mathrm{m}^{-2} \mathrm{~s}^{-1}\right.$ during $\left.1.5 \mathrm{~s}\right)$ were provided by a fiber-optic placed in a grooved neck at $60^{\circ}$ to the leaf surface. Maximal $(F m)$ and basal $(F O)$ fluorescence signals were measured after $30 \mathrm{~min}$ of dark adaptation. Variable fluorescence $(F v)$ was calculated as $F v=F m-F 0$. Instantaneous $(F S)$ and maximum $\left(F m^{\prime}\right)$ fluorescence signals were recorded in light-adapted leaves. Light-adapted variable fluorescence $(\Delta F)$ was obtained as $\Delta F=F m^{\prime}-F s$. The following chlorophyll fluorescence variables were calculated to evaluate photochemical performance under different light conditions: maximum $(F v / F m)$ and actual $\left(\Delta F / F m^{\prime}\right)$ quantum yield of primary photochemistry (Genty et al. 1989) and apparent electron transport rate $(E T R=$ $\left.\Delta F / F m^{\prime} \times Q \times 0.5 \times 0.84\right)$ (Krall \& Edwards 1992). For ETR calculation it was adopted 0.5 as the fraction of excitation energy distributed to PSII and 0.84 was the fraction of total $Q$ absorbed by leaves (Demmig \& Björkman 1987).

Chlorophyll fluorescence was evaluated from 8h00 to $16 \mathrm{~h} 00$ in both forest environments (gap and understorey) during a sunny day. Only maximum and minimum values of $F v / F m, \triangle F / F m$ ' and ETR are shown because we did not find any significant difference in diurnal dynamics of such photochemical variables when comparing the species in the same light environment. Environmental conditions during evaluations of chlorophyll fluorescence in forest gap $(G)$ and understorey $(U)$ in early morning were, respectively: $\mathrm{T}_{\text {air }}=22 \pm 2{ }^{\circ} \mathrm{C}(G)$ and $20 \pm 2{ }^{\circ} \mathrm{C}(U)$; leaf-to-air vapor pressure difference $(\mathrm{VPD})=1.4 \pm 0.2 \mathrm{kPa}$
$(G)$ and $1.6 \pm 0.1 \mathrm{kPa}(U) ; Q=50 \pm 16 \mu \mathrm{mol} \mathrm{m} \mathrm{m}^{-2} \mathrm{~s}^{-1}(G)$ and $30 \pm 5 \mu \mathrm{mol} \mathrm{m} \mathrm{m}^{-2} \mathrm{~s}^{-1}(U)$ in early morning; , and around midday; $\mathrm{T}_{\text {air }}=30 \pm 3{ }^{\circ} \mathrm{C}(G)$ and $27 \pm 3{ }^{\circ} \mathrm{C}(U) ; V P D=2.0 \pm 0.5 \mathrm{kPa}$ $(G)$ and $1.7 \pm 0.2 \mathrm{kPa}(U)$; and $Q=1600 \pm 123 \mu \mathrm{mol} \mathrm{m} \mathrm{m}^{-2} \mathrm{~s}^{-1}$ $(G)$ and $50 \pm 23 \mu \mathrm{mol} \mathrm{m} \mathrm{m}^{-2} \mathrm{~s}^{-1}(U)$ around midday. Air $\mathrm{CO}_{2}$ concentration was $370 \pm 10 \mu \mathrm{mol} \mathrm{mol}{ }^{-1}$ in both sites.

Photosynthetic responses to increasing light $(A / Q)$ and intercellular $\mathrm{CO}_{2}$ concentration $(\mathrm{A} / \mathrm{Ci})$ were evaluated with a portable infrared gas analyzer model CIRAS-2 (PPSystems, UK) in the same leaves used in chlorophyll fluorescence measurements. Leaf $\mathrm{CO}_{2}$ assimilation $(A)$ was measured over a range of $Q$ from 1500 to $0 \mu \mathrm{mol} \mathrm{m} \mathrm{m}^{-2} \mathrm{~s}^{-1}$, after 3 to $5 \mathrm{~min}$. under each $Q$ intensity. This period was enough to reach a coefficient of variation $(\mathrm{CV})$ regarding $\Delta \mathrm{CO}_{2}$ lower than $1.0 \%$. $A / Q$ curves were performed between $9 \mathrm{~h} 00$ and $15 \mathrm{~h} 00$ in a sunny day in both light environments. Leaf gas exchange was evaluated under air $\mathrm{CO}_{2}$ concentration of $370 \pm 10 \mu \mathrm{mol} \mathrm{mol}^{-1}$, while $\mathrm{T}_{\text {air }}$ and VPD were not controlled as our intention was to measure leaf gas exchange near to natural conditions.

The $A / C i$ response curves were also taken using the CIRAS-2 system in the same leaves evaluated in $A / Q$ curves. Intercellular $\mathrm{CO}_{2}$ concentration $(\mathrm{Ci})$ was changed by oversetting the air $\mathrm{CO}_{2}$ concentration $(\mathrm{Ca})$ inside leaf chamber between 0 and $100 \mathrm{~Pa}$ as described by Long \& Bernacchi (2003). Data were recorded when low CV values $(<1.0 \%)$ of $A$ were observed, which occurred after 3 to $5 \mathrm{~min}$ in each $\mathrm{Ca}$ concentration. $\mathrm{A} / \mathrm{Ci}$ curves were performed in both environmental conditions at $Q=1000 \mu \mathrm{mol} \mathrm{m}{ }^{-2} \mathrm{~s}^{-1}$. Some photosynthetic variables were derived from $\mathrm{A} / \mathrm{Ci}$ curves: photosynthetic capacity given by maximum $\mathrm{CO}_{2}$ assimilation; apparent carboxylation efficiency $(k)$ estimated using the initial linear slope of $\mathrm{A} / \mathrm{Ci}$ curves; and relative stomatal limitation of photosynthesis $(L s)$, as proposed by Farquhar \& Sharkey (1982):

$$
L s=\left[\left(A^{\prime}-A\right) / A^{\prime}\right]^{*} 100,
$$

in which: $A^{\prime}$ is the net $\mathrm{CO}_{2}$ assimilation when $\mathrm{Ci}$ is $370 \mu \mathrm{mol} \mathrm{mol}{ }^{-1}, A$ is the net $\mathrm{CO}_{2}$ assimilation under regular $C i\left(220 \pm 10 \mu \mathrm{mol} \mathrm{mol}^{-1}\right)$ when $C a=370 \mu \mathrm{mol} \mathrm{mol}{ }^{-1}$.

Both $A / Q$ and $A / C i$ response curves were fitted using the following equation (Prado \& Moraes 1997):

$$
A=\operatorname{Amax}\left(1-\mathrm{e}^{\mathrm{-c}(\mathrm{x}-\mathrm{CP})}\right),
$$

in which: $A$ is the $\mathrm{CO}_{2}$ assimilation, Amax is the maximum $\mathrm{CO}_{2}$ assimilation (named photosynthetic capacity in $\mathrm{A} / \mathrm{Ci}$ curve), $c$ is the constant related to the curve. The parameter $x$ is $Q$ or $\mathrm{Ci}$, and the parameter $\mathrm{CP}$ is the light or the $\mathrm{CO}_{2}$ compensation point in $A / Q$ and $A / C i$ response curves, respectively. $\mathrm{T}_{\text {air }}$ and VPD during $A / Q$ and $A / C i$ curves were: $28 \pm 2{ }^{\circ} \mathrm{C}$ and $1.6 \pm 0.4 \mathrm{kPa}$ in gap and $26 \pm 4^{\circ} \mathrm{C}$ and $1.7 \pm 0.3 \mathrm{kPa}$ in understorey. At least three $A / Q$ and three $A / C i$ curves were performed per species in each light environment.

The evaluated leaves were collected at the end of measurements and the leaf area was immediately measured 
with a digital planimeter (Li-3000A, Licor, USA). Afterwards, the leaf dry mass was determined and the ratio leaf dry mass per unit of leaf area ( $L M A)$ was calculated. Leaf dry mass was obtained after drying leaf tissues at $60^{\circ} \mathrm{C}$ until constant mass. The maximum $\mathrm{CO}_{2}$ assimilation on area (Aarea) and mass (Amass) basis were calculated. Mass-based shows higher relationship with plant growth than area-based photosynthesis (Reich et al. 1998) and are in accordance to the idea that mass-based evaluations are more relevant to measure plant energetics than area-based gas exchange rates (Reich et al. 1992).

Plant growth and leaf nutritional status - Plant growth was evaluated considering plant height $(H)$ and stem diameter $(D)$ at $5 \mathrm{~cm}$ above soil surface. Growth was estimated considering measurements taken in an interval of six months, starting at planting date. Plant height was measured with metric tape and stem diameter with a digital caliper.

Leaves similar to those evaluated for physiological traits were collected in five plants of each species at each forest site to determine the nutritional status. Leaf contents of nitrogen $(\mathrm{N})$, phosphorus $(\mathrm{P})$, calcium $(\mathrm{Ca})$, magnesium $(\mathrm{Mg})$, iron $(\mathrm{Fe})$ and sulphur (S) were assessed. Leaf $\mathrm{N}$ content was determined by the Kjehldal method, i.e. digestion in concentrated sulfuric acid followed by distillation and titration. The other elements were determined by spectrophotometry of atomic absorption, according to Malavolta et al. (1997). Maximum $\mathrm{CO}_{2}$ assimilation values found in both $A / Q$ and $A / C i$ curves were calculated in both $\mathrm{N}(A N)$ and $\mathrm{P}(A P)$ basis for evaluating the photosynthetic efficiency in relation to these nutrients (Reich et al. 1995) often limiting in tropical soils.

Data analysis - Physiological and nutritional data were subject to analysis of variance (ANOVA, $P=0.05$ ), being the mean values $(n=3$ or 4 for physiological variables; $n=5$ for nutritional data) compared by the Tukey test $(P=0.05)$ when statistical significance was detected. Phenotypic plasticity index $(P P I)$ was estimated from data obtained in $A / C i$ and $A / Q$ curves and from plant growth measures. PPI was calculated for each single physiological parameter between the two forest environment (gap and understorey) following Rozendaal et al. (2006) and Valladares et al. (2006) as:

$P P I=($ maximum mean - minimum mean $)(\text { maximum mean })^{-1}$

\section{Results}

Leaf nutritional status and plant growth - In both sites, the highest leaf $\mathrm{N}$ content was found in pioneer $B$. forficata and in the non-pioneer E. leiocarpa (table 1). Forest environments did not cause changes in leaf $\mathrm{N}$ content when considering the same species, except for G. ulmifolia that showed higher leaf $\mathrm{N}$ content in understorey than in gap. Leaf P content did not show any significant difference between forest environments or among species, ranging from 1.6 to $2.9 \mathrm{mg} \mathrm{g}^{-1}$. With exception of G. ulmifolia, leaf S content was higher in plants grown in forest gap. The concentrations of $\mathrm{Fe}$ was remarkably higher in understorey for all species, mainly in E. leiocarpa. Changes observed on $\mathrm{Ca}$ and $\mathrm{Mg}$ leaf contents between environments were not related to plant species (table 1).

Leaf mass per area (LMA) was significantly higher in forest gap than in understorey for all species, except for the non-pioneer $H$. courbaril that exhibited low PPI (0.04) of LMA between environments (table 2). G. ulmifolia, $H$. courbaril and E. leiocarpa showed higher and similar $L M A$ in forest gap. Non-pioneers $H$. courbaril and E. leiocarpa had higher $L M A$ than pioneers in understorey (table 2). In forest gap, pioneer species $B$. forficata showed the tallest individuals as well as the greatest stem diameter. There was non-significant difference in plant height between pioneer G. ulmifolia and non-pioneer E. leiocarpa in forest gap (table 2).

Table 1. Leaf contents of nitrogen $(\mathrm{N})$, phosphorus $(\mathrm{P})$, calcium $(\mathrm{Ca})$, magnesium $(\mathrm{Mg})$, iron $(\mathrm{Fe})$ and sulphur $(\mathrm{S})$ in pioneer (Guazuma ulmifolia, Bauhinia forficata) and non-pioneer (Hymenaea courbaril, Esenbeckia leiocarpa) tropical tree species grown under forest gap $(G)$ and in understorey $(U)$. Different capital letters indicate significant $(P<0.05)$ difference among species in the same site and different small letters significant difference between sites for the same species. ns denotes non-significant differences $(P>0.05)$. Data refer to mean values $(n=5)$.

\begin{tabular}{|c|c|c|c|c|c|c|c|c|}
\hline \multirow{3}{*}{ Nutrient content } & \multicolumn{4}{|c|}{ Pioneers } & \multicolumn{4}{|c|}{ Non-pioneers } \\
\hline & \multicolumn{2}{|c|}{ G. ulmifolia } & \multicolumn{2}{|c|}{ B. forficata } & \multicolumn{2}{|c|}{ H. courbaril } & \multicolumn{2}{|c|}{ E. leiocarpa } \\
\hline & G & $U$ & $G$ & $U$ & $G$ & $U$ & $G$ & $U$ \\
\hline $\mathrm{N}\left(\mathrm{mg} \mathrm{g}^{-1}\right)$ & $19.7^{\mathrm{Bb}}$ & $24.4^{\mathrm{Ba}}$ & $31.9^{\mathrm{Aa}}$ & $32.7^{\mathrm{Aa}}$ & $19.0^{\mathrm{Ba}}$ & $17.4^{\mathrm{Ca}}$ & $31.4^{\mathrm{Aa}}$ & $28.5^{\mathrm{ABa}}$ \\
\hline $\mathrm{P}\left(\mathrm{mg} \mathrm{g}^{-1}\right)$ & $1.8^{\mathrm{ns}}$ & 2.9 & 1.2 & 1.7 & 2.0 & 1.6 & 2.2 & 2.2 \\
\hline $\mathrm{Ca}\left(\mathrm{mg} \mathrm{g}^{-1}\right)$ & $8.0^{\mathrm{Ab}}$ & $12.5^{\mathrm{Aa}}$ & $4.8^{\mathrm{ABa}}$ & $5.7^{\mathrm{Ba}}$ & $2.1^{\mathrm{Bb}}$ & $4.1^{\mathrm{Ba}}$ & $10.0^{\mathrm{Aa}}$ & $6.2^{\mathrm{Bb}}$ \\
\hline $\operatorname{Mg}\left(\mathrm{mg} \mathrm{g}^{-1}\right)$ & $4.8^{\mathrm{Ab}}$ & $5.9^{\mathrm{Aa}}$ & $3.0^{\mathrm{Ba}}$ & $3.1^{\mathrm{Ba}}$ & $2.1^{\mathrm{Ba}}$ & $2.2^{\mathrm{Ba}}$ & $2.2^{\mathrm{Bb}}$ & $3.8^{\mathrm{ABa}}$ \\
\hline $\mathrm{S}\left(\mathrm{mg} \mathrm{g}^{-1}\right)$ & $4.0^{\mathrm{Aa}}$ & $3.9^{\mathrm{Aa}}$ & $4.2^{\mathrm{Aa}}$ & $3.0^{\mathrm{Ab}}$ & $3.3^{\mathrm{Ba}}$ & $2.3^{\mathrm{Bb}}$ & $3.3^{\mathrm{Ba}}$ & $1.9^{\mathrm{Bb}}$ \\
\hline $\mathrm{Fe}\left(\mu \mathrm{g} \mathrm{g}^{-1}\right)$ & $73.7^{\mathrm{Bb}}$ & $214.3^{\mathrm{ABa}}$ & $45.7^{\mathrm{Bb}}$ & $119.7^{\mathrm{Ba}}$ & $46.0^{\mathrm{Bb}}$ & $172.3^{\mathrm{Ba}}$ & $153.3^{\mathrm{Ab}}$ & $305.0^{\mathrm{Aa}}$ \\
\hline
\end{tabular}


Individuals grown in understorey were shorter than those grown in gap, except for G. ulmifolia that showed the lowest PPI (0.03). Stem diameter was also higher in gap than in understorey conditions, with exception of $H$. courbaril (table 2). Taking into account plant growth traits, $H$. courbaril showed low values of $P P I$, while B. forficata and E. leiocarpa exhibited high PPI (table 2).

Table 2. Leaf mass per area (LMA), plant height $(H)$ and stem diameter $(D)$ in pioneer (Guazuma ulmifolia, Bauhinia forficata) and non-pioneer (Hymenaea courbaril, Esenbeckia leiocarpa) tropical tree species grown in forest gap $(G)$ and understorey $(U)$. Different capital letters indicate significant $(P<0.05)$ difference among species in same site while different small letters indicate significant differences between sites for same species. Data refer to mean values $(n=5)$. Phenotypic plasticity index $(P P I)$ for each variable between environments is shown in italics.

\begin{tabular}{|c|c|c|c|c|c|c|c|c|}
\hline \multirow{3}{*}{ Variables } & \multicolumn{4}{|c|}{ Pioneers } & \multicolumn{4}{|c|}{ Non-pioneers } \\
\hline & \multicolumn{2}{|c|}{ G. ulmifolia } & \multicolumn{2}{|c|}{ B. forficata } & \multicolumn{2}{|c|}{ H. courbaril } & \multicolumn{2}{|c|}{ E. leiocarpa } \\
\hline & $G$ & $U$ & $G$ & $U$ & $G$ & $U$ & $G$ & $U$ \\
\hline$L M A\left(\mathrm{mg} \mathrm{cm}^{-2}\right)$ & $4.8^{\mathrm{ABa}}$ & $2.4^{\mathrm{Bb}}$ & $4.0^{\mathrm{Ba}}$ & $1.7^{\mathrm{Bb}}$ & $4.9^{\mathrm{ABa}}$ & $4.7^{\mathrm{Aa}}$ & $5.8^{\mathrm{Aa}}$ & $3.1^{\mathrm{ABb}}$ \\
\hline$P P I$ & \multicolumn{2}{|c|}{0.50} & \multicolumn{2}{|c|}{0.57} & \multicolumn{2}{|c|}{0.04} & \multicolumn{2}{|c|}{0.46} \\
\hline$H(\mathrm{~cm})$ & $146^{\mathrm{Ba}}$ & $142^{\mathrm{Aa}}$ & $225^{\mathrm{Aa}}$ & $77^{\mathrm{Bb}}$ & $95^{\mathrm{Ca}}$ & $78^{\mathrm{Bb}}$ & $160^{\mathrm{Ba}}$ & $68^{\mathrm{Bb}}$ \\
\hline$P P I$ & \multicolumn{2}{|c|}{0.03} & \multicolumn{2}{|c|}{0.66} & \multicolumn{2}{|c|}{0.18} & \multicolumn{2}{|c|}{0.57} \\
\hline$D(\mathrm{~cm})$ & $22^{\mathrm{Ba}}$ & $13^{\mathrm{Ab}}$ & $27^{\mathrm{Aa}}$ & $7^{\mathrm{Bb}}$ & $15^{\mathrm{Ca}}$ & $13^{\mathrm{Aa}}$ & $21^{\mathrm{Ba}}$ & $6^{\mathrm{Bb}}$ \\
\hline$P P I$ & \multicolumn{2}{|c|}{0.41} & \multicolumn{2}{|c|}{0.74} & \multicolumn{2}{|c|}{0.13} & \multicolumn{2}{|c|}{0.71} \\
\hline
\end{tabular}

Chlorophyll fluorescence in forest gap and understorey - Irrespective to functional groups (pioneer and nonpioneer), diurnal light changes had similar effects on plant photochemistry in both forest environments. High light availability around midday in gap resulted in significant decrease of maximum $(F v / F m)$ and actual $\left(\Delta F / F m^{\prime}\right)$ quantum yield of primary photochemistry and significant increase of apparent electron transport rate $(E T R)$ in all tree species (figure 1A,C,E). On the other hand, tree species showed similar values of $F v / F m$, $\triangle F / F m$ ' and ETR in early morning and around midday in forest understorey, where there was low light availability throughout the daytime (figure 1B,D,F). Pioneer and non-pioneer species did not exhibit significant differences about $F v / F m, \Delta F / F m$ ' and $E T R$ in both light environments (figure 1).

Plasticity in photosynthetic response to light ( $A / Q$ curves) - Differences in initial linear region, maximum $A$, and light saturation of $A$ were observed comparing a same species in both environments (figure 2A, C, E, G and table 3). Maximum $\mathrm{CO}_{2}$ assimilation per area (Aarea), mass (Amass) and on leaf $\mathrm{N}$ content $(A N)$ bases were significantly higher in forest gap than in understorey in all species, with exception of non-pioneer E. leiocarpa that showed relatively low PPI values (table 3 ). Pioneer B. forficata showed the highest Aarea in forest gap. $A N$ was quite similar among species grown in forest gap, except for E. leiocarpa. In understorey, there were

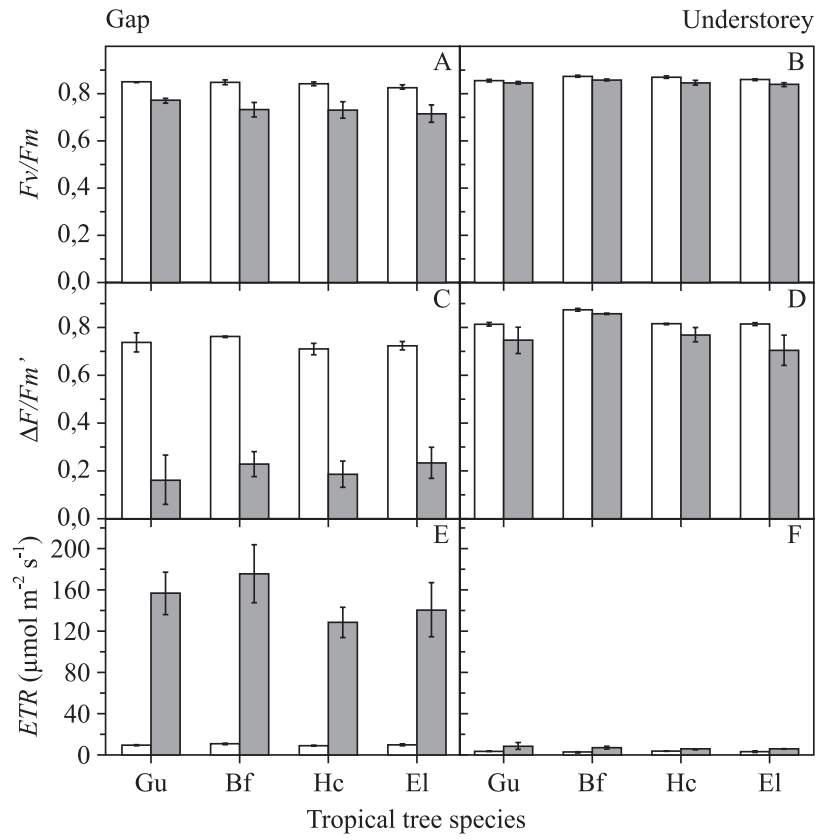

Figure 1. Maximum $(F v / F m$, in A-B $)$ and actual $\left(\Delta F / F m^{\prime}\right.$, in $\mathrm{C}$-D) quantum yield of primary photochemistry and apparent electron transport rate (ETR, in E-F) in early morning (07h30, white column) and around midday (11h00, grey column) in pioneer $(\mathrm{Gu}=$ Guazuma ulmifolia $; \mathrm{Bf}=$ Bauhinia forficata $)$ and non-pioneer $(\mathrm{Hc}=$ Hymenaea courbaril $; \mathrm{El}=$ Esenbeckia leiocarpa) tropical tree species grown under forest gap (A, C, E) and understorey (B, D, F). Each column represents the mean value \pm standard deviation $(n=3)$. Gray columns represent data recorded at midday and white columns represent data recorded at early morning. 

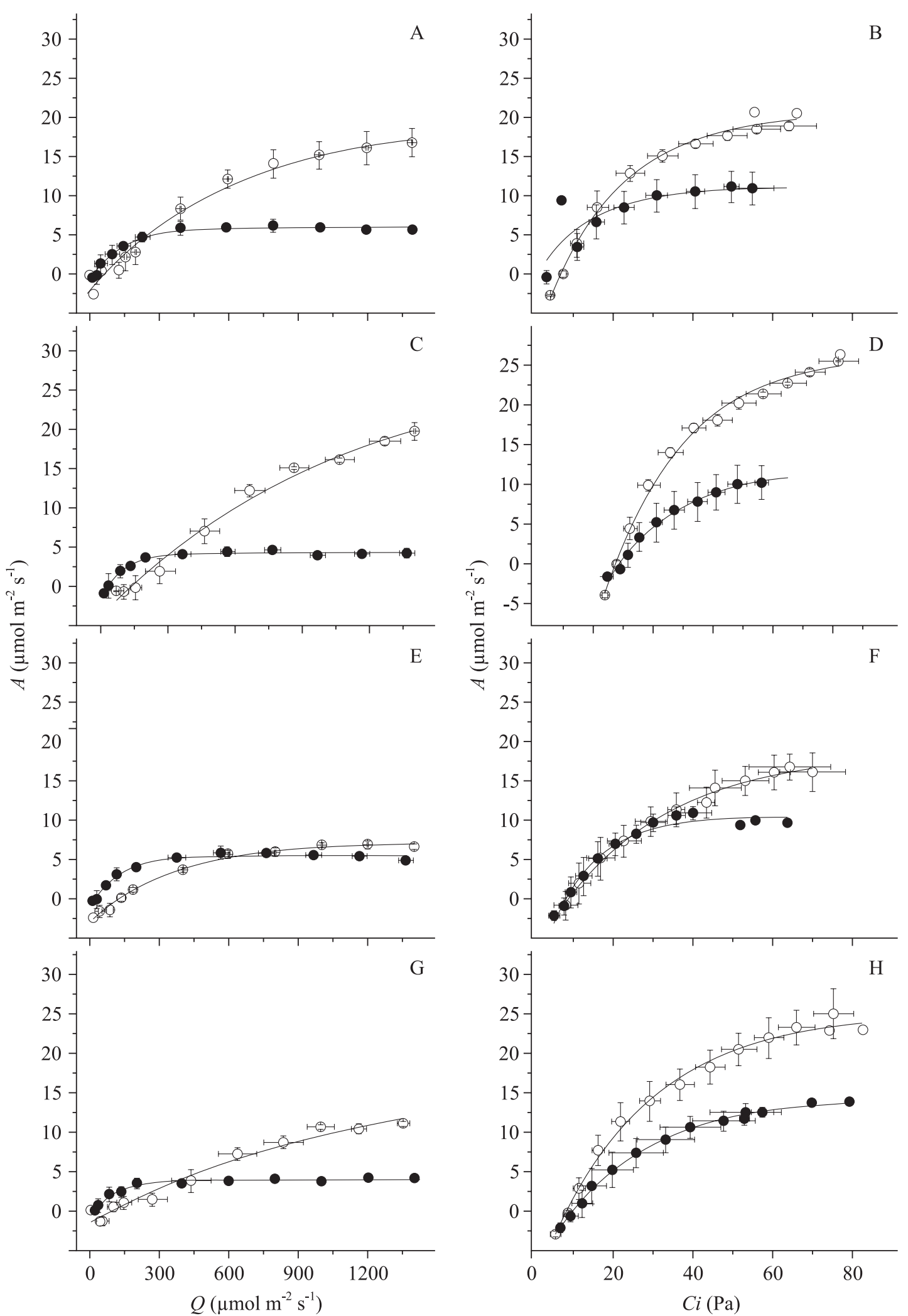

Figure 2. Response of leaf $\mathrm{CO}_{2}$ assimilation to increasing photosynthetic photon flux density $(A / Q$ curves in $\mathrm{A}, \mathrm{C}, \mathrm{E}, \mathrm{G})$ and intercellular $\mathrm{CO}_{2}$ concentration ( $\mathrm{A} / \mathrm{Ci}$ curves in $\mathrm{B}, \mathrm{D}, \mathrm{F}, \mathrm{H}$ ) in pioneer (Guazuma ulmifolia, in A, B; Bauhinia forficata in C, D) and non-pioneer (Esenbeckia leiocarpa, in E, F; Hymenaea courbaril, in G, H) tropical tree species grown in forest gap (open circles) and in understorey (closed circles). Each symbol is the mean value \pm standard deviation $(n=3)$. $(\bullet=$ understorey, $\mathrm{O}=$ gap). 
no significant differences among tree species when considering Aarea and AN; but Amass was significantly higher in $B$. forficata (table 3). The $\mathrm{CO}_{2}$ assimilation per mol of leaf $\mathrm{P}(A P)$ was significantly higher in gap (with exception of $E$. leiocarpa) despite non-significant differences in leaf $\mathrm{P}$ content among species in both sites (tables 1 and 3). Differences in $A P$ among species were smoothed in understorey (table 3 ) and the pioneer $B$. forficata showed the highest $A P$ in both environments.

The overall quantum yield $(\alpha)$ was higher in plants of both functional groups growing in understorey, but $G$. ulmifolia and E. leiocarpa showed the same efficiency of light use between environments (table 3). Low $\alpha$ values were found in non-pioneer species in both forest gap $(H$. courbaril) and understorey (E. leiocarpa). Light compensation $(L C P)$ and saturation $(L S P)$ points were consistently higher in plants grown in forest gap than in understorey. The highest and the lowest $L C P$ were observed in non-pioneer species, E. leiocarpa and $H$. courbaril, respectively (table 3 ). Regardless of tree species, leaf dark respiration $(R d)$ was at least two-fold higher in forest gap than in understorey. The non-pioneer species $H$. courbaril showed the lowest $R d$ values in both environments (table 3 ).

Plasticity in photosynthetic response to intercellular $\mathrm{CO}_{2}$ concentration $(A / C i$ curves) - In average (table 4), the non-pioneer species $H$. courbaril showed PPI values (0.45) two-fold higher than the other species (0.25). Higher photosynthetic capacity (given by the maximum $A$ value) was observed in forest gap, where $A$ saturation by $C i$ and the initial linear slope of $A / C i$ curve were usually higher than in understorey (figure 2). The pioneer B. forficata showed the highest Amass in forest gap (table 4). However, net photosynthesis measured on area bases was similar in B. forficata and $H$. courbaril, a non-pioneer species with relative high $A N$ in both forest sites. Non-pioneer species E. leiocarpa exhibited the lowest values of Aarea, Amass and $A N$ in gap (table 4). In general, Amass was similar between environments (table 4) whereas Aarea was consistently lower in understorey than in gap for all tree species. One exception was $H$. courbaril that exhibited higher Amass and $A N$ in gap than in understorey.

Table 3. Photosynthetic variables derived from $A / Q$ curves performed in leaves of pioneer (Guazuma ulmifolia, Bauhinia forficata) and non-pioneer (Hymenaea courbaril, Esenbeckia leiocarpa) species grown in forest gap $(G)$ and understorey $(U)$ : maximum $\mathrm{CO}_{2}$ assimilation expressed on area (Aarea, $\left.\mu \mathrm{mol} \mathrm{m}^{-2} \mathrm{~s}^{-1}\right)$, mass (Amass, $\left.\mathrm{nmol} \mathrm{g}^{-1} \mathrm{~s}^{-1}\right), \mathrm{N}\left(A N, \mu \mathrm{mol} \mathrm{mol} \mathrm{N} \mathrm{N}^{-1} \mathrm{~s}^{-1}\right)$ and $\mathrm{P}$

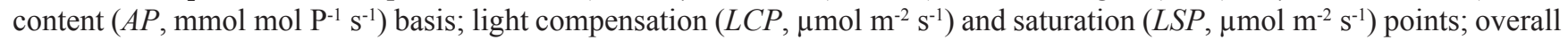
quantum yield $\left(\alpha, \mu \mathrm{mol} \mathrm{mol}^{-1}\right)$ and leaf dark respiration $\left(R d, \mu \mathrm{mol} \mathrm{m}^{-2} \mathrm{~s}^{-1}\right)$. Different capital letters indicate significant $(P<0.05)$ difference among species in same site and different small letters significant difference between sites for same species. Data refer to mean values $(n=3$ or 4$)$. Phenotypic plasticity index $(P P I)$ for each variable between environments is shown in italics.

\begin{tabular}{|c|c|c|c|c|c|c|c|c|}
\hline \multirow{3}{*}{ Derived variables } & \multicolumn{4}{|c|}{ Pioneers } & \multicolumn{4}{|c|}{ Non-pioneers } \\
\hline & \multicolumn{2}{|c|}{ G. ulmifolia } & \multicolumn{2}{|c|}{ B. forficata } & \multicolumn{2}{|c|}{ H. courbaril } & \multicolumn{2}{|c|}{ E. leiocarpa } \\
\hline & G & $U$ & $G$ & $U$ & G & $U$ & G & $U$ \\
\hline Aarea & $15.1^{\mathrm{Ba}}$ & $3.8^{\mathrm{Ab}}$ & $27.5^{\mathrm{Aa}}$ & $4.2^{\mathrm{Ab}}$ & $17.3^{\mathrm{Ba}}$ & $5.9^{\mathrm{Ab}}$ & $6.9^{\mathrm{Ca}}$ & $5.3^{\mathrm{Aa}}$ \\
\hline$P P I$ & \multicolumn{2}{|c|}{0.75} & \multicolumn{2}{|c|}{0.85} & \multicolumn{2}{|c|}{0.66} & \multicolumn{2}{|c|}{0.23} \\
\hline Amass & $329.5^{\mathrm{Ba}}$ & $161.6^{\mathrm{Bb}}$ & $686.0^{\mathrm{Aa}}$ & $262.1^{\mathrm{Ab}}$ & $360.1^{\mathrm{Ba}}$ & $126.9^{\mathrm{Bb}}$ & $120.1^{\mathrm{Ca}}$ & $170.8^{\mathrm{Ba}}$ \\
\hline$P P I$ & \multicolumn{2}{|c|}{0.51} & \multicolumn{2}{|c|}{0.62} & \multicolumn{2}{|c|}{0.65} & \multicolumn{2}{|c|}{0.30} \\
\hline$A N$ & $234.6^{\mathrm{Aa}}$ & $94.2^{\mathrm{Ab}}$ & $301.4^{\mathrm{Aa}}$ & $114.2^{\mathrm{Ab}}$ & $262.2^{\mathrm{Aa}}$ & $102.4^{\mathrm{Ab}}$ & $54.1^{\mathrm{Ba}}$ & $84.8^{\mathrm{Aa}}$ \\
\hline$P P I$ & \multicolumn{2}{|c|}{0.60} & \multicolumn{2}{|c|}{0.62} & \multicolumn{2}{|c|}{0.61} & \multicolumn{2}{|c|}{0.36} \\
\hline$A P$ & $5.7^{\mathrm{Ba}}$ & $2.1^{\mathrm{Bb}}$ & $17.7^{\mathrm{Aa}}$ & $5.3^{\mathrm{Ab}}$ & $5.6^{\mathrm{Ba}}$ & $2.7^{\mathrm{Bb}}$ & $1.7^{\mathrm{Ca}}$ & $2.4^{\mathrm{Ba}}$ \\
\hline$P P I$ & \multicolumn{2}{|c|}{0.63} & \multicolumn{2}{|c|}{0.70} & \multicolumn{2}{|c|}{0.52} & \multicolumn{2}{|c|}{0.29} \\
\hline$\alpha$ & $0.032^{\mathrm{Aa}}$ & $0.032^{\mathrm{Aa}}$ & $0.022^{\mathrm{Ab}}$ & $0.043^{\mathrm{Aa}}$ & $0.015^{\mathrm{Bb}}$ & $0.031^{\mathrm{ABa}}$ & $0.024^{\mathrm{Aa}}$ & $0.026^{\mathrm{Ba}}$ \\
\hline$P P I$ & \multicolumn{2}{|c|}{0.0} & \multicolumn{2}{|c|}{0.49} & \multicolumn{2}{|c|}{0.52} & \multicolumn{2}{|c|}{0.08} \\
\hline$L C P$ & $75^{\mathrm{Ba}}$ & $29^{\mathrm{Bb}}$ & $138^{\mathrm{Aa}}$ & $39^{\mathrm{Bb}}$ & $118^{\mathrm{Aa}}$ & $20^{\mathrm{Cb}}$ & $172^{\mathrm{Aa}}$ & $54^{\mathrm{Ab}}$ \\
\hline$P P I$ & \multicolumn{2}{|c|}{0.61} & \multicolumn{2}{|c|}{0.72} & \multicolumn{2}{|c|}{0.83} & \multicolumn{2}{|c|}{0.69} \\
\hline$L S P$ & $987^{\mathrm{Aa}}$ & $591^{\mathrm{Ab}}$ & $1192^{\mathrm{Aa}}$ & $527^{\mathrm{Ab}}$ & $1195^{\mathrm{Aa}}$ & $605^{\mathrm{Ab}}$ & $992^{\mathrm{Aa}}$ & $581^{\mathrm{Ab}}$ \\
\hline$P P I$ & \multicolumn{2}{|c|}{0.40} & \multicolumn{2}{|c|}{0.56} & \multicolumn{2}{|c|}{0.49} & \multicolumn{2}{|c|}{0.41} \\
\hline$R d$ & $3.2^{\mathrm{Aa}}$ & $0.7^{\mathrm{Bb}}$ & $3.2^{\mathrm{Aa}}$ & $1.7^{\mathrm{Aa}}$ & $1.7^{\mathrm{Ba}}$ & $0.4^{\mathrm{Bb}}$ & $3.1^{\mathrm{Aa}}$ & $1.3^{\mathrm{Ab}}$ \\
\hline$P P I$ & & & & & & & & \\
\hline
\end{tabular}


Table 4. Photosynthetic variables derived from A/Ci curves performed on leaves of pioneer (Guazuma ulmifolia, Bauhinia forficata) and non-pioneer (Hymenaea courbaril, Esenbeckia leiocarpa) tropical tree species grown under forest gap

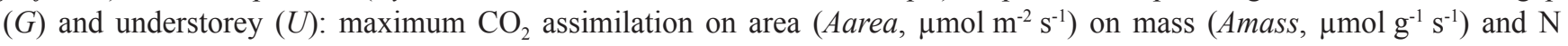
$\left(A N, \mu \mathrm{mol} \mathrm{mol} \mathrm{N}-1 \mathrm{~s}^{-1}\right)$ basis; apparent carboxylation efficiency $\left(k, \mu \mathrm{mol} \mathrm{m}^{-2} \mathrm{~s}^{-1} \mathrm{~Pa}^{-1}\right)$; and stomatal limitation of photosynthesis $(L s, \%)$. Different capital letters indicate significant $(P<0.05)$ difference among species in same site and different small letters significant differences between sites for same species. Data refer to mean values $(n=3$ or 4$)$. Phenotypic plasticity index $(P P I)$ for each variable between environments is shown in italics.

\begin{tabular}{|c|c|c|c|c|c|c|c|c|}
\hline \multirow{3}{*}{ Derived variables } & \multicolumn{4}{|c|}{ Pioneers } & \multicolumn{4}{|c|}{ Non-pioneers } \\
\hline & \multicolumn{2}{|c|}{ G. ulmifolia } & \multicolumn{2}{|c|}{ B. forficata } & \multicolumn{2}{|c|}{ H. courbaril } & \multicolumn{2}{|c|}{ E. leiocarpa } \\
\hline & $G$ & $U$ & $G$ & $U$ & $G$ & $U$ & $G$ & $U$ \\
\hline Aarea & $19.5^{\mathrm{Ba}}$ & $11.6^{\mathrm{Ab}}$ & $25.6^{\mathrm{Aa}}$ & $12.5^{\mathrm{Ab}}$ & $26.4^{\mathrm{Aa}}$ & $14.2^{\mathrm{Ab}}$ & $18.4^{\mathrm{Ba}}$ & $12.1^{\mathrm{Ab}}$ \\
\hline$P P I$ & \multicolumn{2}{|c|}{0.40} & \multicolumn{2}{|c|}{0.51} & \multicolumn{2}{|c|}{0.46} & \multicolumn{2}{|c|}{0.34} \\
\hline Amass & $415.6^{\mathrm{Ba}}$ & $485.8^{\mathrm{Ba}}$ & $645.2^{\mathrm{Aa}}$ & $778.0^{\mathrm{Aa}}$ & $547.5^{\mathrm{ABa}}$ & $305.1^{\mathrm{Bb}}$ & $327.5^{\mathrm{Ba}}$ & $383.3^{\mathrm{Ba}}$ \\
\hline$P P I$ & \multicolumn{2}{|c|}{0.14} & \multicolumn{2}{|c|}{0.17} & \multicolumn{2}{|c|}{0.79} & \multicolumn{2}{|c|}{0.15} \\
\hline$A N$ & $296.1^{\mathrm{Ba}}$ & $278.9^{\mathrm{ABa}}$ & $284.1^{\mathrm{Ba}}$ & $338.5^{\mathrm{Aa}}$ & $406.0^{\mathrm{Aa}}$ & $246.3^{\mathrm{ABb}}$ & $149.3^{\mathrm{Ca}}$ & $188.9^{\mathrm{Ca}}$ \\
\hline$P P I$ & \multicolumn{2}{|c|}{0.06} & \multicolumn{2}{|c|}{0.16} & \multicolumn{2}{|c|}{0.39} & \multicolumn{2}{|c|}{0.20} \\
\hline$k$ & $0.090^{\mathrm{Aa}}$ & $0.053^{\mathrm{Ab}}$ & $0.090^{\mathrm{Aa}}$ & $0.051^{\mathrm{Ab}}$ & $0.095^{\mathrm{Aa}}$ & $0.061^{\mathrm{Ab}}$ & $0.060^{\mathrm{Ba}}$ & $0.058^{\mathrm{Aa}}$ \\
\hline$P P I$ & \multicolumn{2}{|c|}{0.41} & \multicolumn{2}{|c|}{0.43} & \multicolumn{2}{|c|}{0.36} & \multicolumn{2}{|c|}{0.03} \\
\hline$L s$ & $16.2^{\mathrm{Ba}}$ & $20.1^{\mathrm{ABa}}$ & $20.2^{\mathrm{Ba}}$ & $22.1^{\mathrm{Aa}}$ & $34.3^{\mathrm{Aa}}$ & $26.3^{\mathrm{Ab}}$ & $31.4^{\mathrm{Aa}}$ & $14.1^{\mathrm{Bb}}$ \\
\hline$P P I$ & \multicolumn{2}{|c|}{0.19} & \multicolumn{2}{|c|}{0.09} & \multicolumn{2}{|c|}{0.23} & \multicolumn{2}{|c|}{0.55} \\
\hline
\end{tabular}

All species had higher apparent carboxylation efficiency $(k)$ in gap than in understorey, with exception of E. leiocarpa that had low PPI (0.03). The stomatal limitation of photosynthesis $(L s)$ was high $(>30 \%)$ in non-pioneer species grown in forest gap (table 4).

\section{Discussion}

Our results indicated that tree species of different successional status were able to acclimate under contrasting light availabilities, exhibiting changes in leaf morphology (table 2) and photosynthesis (tables 3 and 4), as well as in leaf nutritional contents (table 1). For instance, the non-pioneer species $H$. courbaril exhibited the same trend observed in pioneer species (figure $2 \mathrm{G}$ ), with high photosynthetic plasticity and high acclimation capacity to high light availability under gap conditions. In fact, some shade-tolerant or non-pioneer species may have significant ability to increase photosynthetic capacity in response to increasing light availability but this adjustment has been observed within a restricted range of light conditions (Chazdon 1992, Chazdon et al. 1996). Moreover, similar photochemical responses (figure 1) indicated that pioneer and non-pioneer species have similar acclimation capacity of photochemical apparatus in contrasting light environments. This assumption is supported by the non-occurrence of chronic photoinhibition in non-pioneer species grown in forest gap (given by high $F v / F m$ in early morning shown in figure 1) as well as by high $A$ values found in pioneer species grown in forest understorey (figure 2). Accordingly, Ribeiro et al. (2005) did not find patterns of photochemical response between pioneer and non-pioneer species when growing seven tropical tree species under contrasting irradiance regimes.

The phenotypic plasticity was variable among species, as indicated by PPI. For instance, the nonpioneer species $H$. courbaril showed the lowest $P P I$ in growth traits (table 2), while it exhibited high PPI values in photosynthetic traits, similar to those found in pioneer species (tables 3 and 4). Additionally, $E$. leiocarpa (non-pioneer) showed high plasticity in growth (table 2) and relatively low plasticity in photosynthesis (table 3). The pioneer species $B$. forficata exhibited high plasticity in all physiological traits, while plasticity in G. ulmifolia varied according to the set of physiological traits observed.

Our data revealed that pioneer and non-pioneer tree species have similar photosynthetic plasticity despite the differences in their leaf nutritional status. This conclusion is in accordance with Turnbull (1991), Popma et al. (1992) and Ellis et al. (2000). These authors reported that some late successional species are also sensitive to variations in light environment and have high capacity of photosynthetic acclimation. Additionally, the study of Rozendaal et al. (2006) with 38 tropical tree species 
reported that short-lived pioneer species showed the lowest plasticity to irradiance.

Alternative hypotheses about plasticity in successional groups should be considered to understand forest dynamics. According to Popma et al. (1992), plasticity is greater for all species that experience a large ontogenetic change in irradiance during life cycle. Another hypothesis states that plasticity in pioneer and non-pioneer species is greater for those leaf traits that are more important for successful performance in high or low light environment (Valladares et al. 2002). Accordingly, many shade-tolerant species have significant plasticity of photosynthetic capacity within a range from $1 \%$ to $20 \%$ of full sunlight, which is commonly found in small gaps (Chazdon et al. 1996). Late successional species in our study were grown under gap conditions with nearly $70 \%$ of full sunlight, indicating significant photosynthetic plasticity.

In conclusion, the data presented herein have ecophysiological relevance since small gaps are far more frequent than large ones, accounting for virtually a large part of the environment dynamics in a semideciduous forest (Martins \& Rodrigues 2002). Furthermore, some phytossociological studies in tropical forest succession have shown that late successional species play a significant role in gap restoration, which clearly indicates the ability of such group to face the environmental fluctuations in forest gap (Tabarelli \& Mantovani 1999, Martinez-Garza et al. 2005). Accordingly, our data support the assumption that some species considered as late successional could co-exist with pioneer species under similar environmental conditions. Therefore, the gap regeneration, mainly the small ones, would include the participation of pioneer and non-pioneer species (specially those with high phenotypic plasticity) at the same time, which could also be considered as a basis for recovery of degraded areas.

Acknowledgements - This study was supported by the Fundação de Amparo a Pesquisa do Estado de São Paulo (Fapesp, grant no ${ }^{\circ}$ 03/06939-5). G.M.S., R.V.R. and C.H.B.A.P. are grateful to the Conselho Nacional de Desenvolvimento Científico e Tecnológico (CNPq) for fellowships granted.

\section{References}

ATKIN, O.K. \& TJOELKER, M.G. 2003. Thermal acclimation and the dynamic response of plant respiration to temperature. Trends in Plant Science 8:343-351.

BAZZAZ, F.A. 1979. The physiological ecology of plant succession. Annual Review of Ecology and Systematics 10:351-371.
BAZZAZ, F.A. 1996. Plants in changing environment: linking physiological, population and community ecology. Cambridge University Press, Cambridge.

BAZZAZ, F.A. \& PICKETT, S.T.A. 1980. Physiological ecology of tropical succession: a comparative review. Annual Review of Ecology and Systematics 11:287-310.

CHAZDON, R.L. 1992. Photosynthetic plasticity of two rainforest shrubs across natural gap transects. Oecologia 92:586-595.

CHAZDON, R.L., PEARCY, R.W., LEE, D.W. \& FETCHER, N. 1996. Photosynthetic responses of tropical forest plants to contrasting light environments. In Tropical forest plant ecophysiology (S.S. Mulkey, R.L. Chazdon \& A.P. Smith, eds.). Chapman \& Hall, New York, p.5-55.

DEMMIG, B. \& BJÖRKMAN, O. 1987. Comparison of the effects of excessive light on chlorophyll fluorescence and photon yield of $\mathrm{O}_{2}$ evolution in leaves of higher plants. Planta 171:171-184.

ELLIS, A.R., HUBBELL, S.P. \& POTVIN, C. 2000. In situ field measurements of photosynthetic rates of tropical tree species: a test of the functional group hypothesis. Canadian Journal of Botany 78:1336-1347.

FARQUHAR, G.D. \& SHARKEY, T.D. 1982. Stomatal conductance and photosynthesis. Annual Review of Plant Physiology 33:317-345.

FLEXAS, J, BOTA, J., GALMÊS, J., MEDRANO, H. \& RIBAS-CARBÓ, M. 2006. Keeping a positive carbon balance under adverse conditions: responses of photosynthesis and respiration to water stress. Physiologia Plantarum 127:343-352.

GENTY, B., BRIANTAIS, J.M. \& BAKER, N.R. 1989. The relationship between quantum yield of photosynthetic electron transport and quenching of chlorophyll fluorescence. Biochemica et Biophysica Acta 990:87-92.

HOOPER, D. 1998. The role of complementarity and competition in ecosystem responses to variation in plant diversity. Ecology 79:704-719.

KOIKE, T. 1988. Leaf structure and photosynthetic performance as related to the forest succession of deciduous broad-leaved trees. Plants Species Biology 3:77-87.

KRALL, J.P. \& EDWARDS, G.E. 1992. Relationship between photosystem activity and $\mathrm{CO}_{2}$ fixation in leaves. Physiologia Plantarum 86:180-187.

LAVOREL, S., MCINTYRE, S., LANDSBERG, J. \& FORBES, T.D.A. 1997. Plant functional classifications: from general groups to specific groups based on response to disturbance. Trends in Ecology and Evolution 12:474-478.

LONG, S.P. \& BERNACCHI, C.J. 2003. Gas exchange measurements, what can they tell us about the underlying limitations to photosynthesis? Procedures and sources of error. Journal of Experimental Botany 54:2393-2401. 
LORENZI, H. 1992. Árvores brasileiras: manual de identificação e cultivo de plantas arbóreas nativas do Brasil. Plantarum, Nova Odessa.

MALAVOLTA, E., VITTI. G.C. \& OLIVEIRA, S.A. 1997. Avaliação do estado nutricional das plantas: princípios e aplicações. $2^{\mathrm{a}}$ ed. Potafos, Piracicaba.

MARTINEZ-GARZA, C., PEÑA, V., RICKER, M., CAMPOS, A. \& HOWE, H.F. 2005. Restoring tropical biodiversity: leaf traits predict growth and survival of latesuccessional trees in early-successional environments. Forest, Ecology and Management 217:365-379.

MARTINS, S.V. \& RODRIGUES, R.R. 2002. Gap-phase regeneration in a semideciduous mesophytic Forest, south-eastern Brazil. Plant Ecology 163:51-62.

PEARCY, R.W. 1987. Photosynthetic gas exchange responses of Australian tropical forest trees in canopy, gap and understorey micro-environments. Functional Ecology 1:169-178.

POPMA, J., BONGERS, F. \& WERGER, M.J.A. 1992. Gapdependence and leaf characteristics of trees in a tropical rain forest in Mexico. Oikos 63:207-214.

PRADO, C.H.B.A. \& MORAES, J.A.P.V. 1997. Photosynthetic capacity and specific leaf mass in twenty woody species of cerrado vegetation under field conditions. Photosynthetica 33:103-112.

RAAIMAKERS, D., BOOT, R.G.A., DIJKSTRA, P., POT. S. \& PONS, T. 1995. Photosynthetic rates in relation to leaf phosphorus content in pioneer versus climax tropical rain forest trees. Oecologia 102:120-125.

REICH, P.B., WALTERS, M.B. \& ELLSWORTH, D.S. 1992. Leaf lifespan in relation to leaf, plant and stand characteristics among diverse ecosystems. Ecological Monographs 62:365-392.

REICH, P.B., KLOEPPEL, B.D., ELLSWORTH, D.S. \& WALTERS, M.B. 1995. Different photosynthesisnitrogen relations in deciduous hardwood and evergreen coniferous tree species. Oecologia 104:24-30.

REICH, P.B., WALTERS, M.B., TJOELKER, M.G., VANDERKLEIN, D. \& BUSCHENA, C. 1998. Photosynthesis and respiration rates depend on leaf and root morphology and nitrogen concentration in nine boreal tree species differing in relative growth rate. Functional Ecology 12:395-405.

REICH, P.B., BUSCHERA, C., TJOELKER, M.G., WRAGE, K., KNOPS, J., TILMAN, D. \& MACHADO, J.L. 2003. Variation in growth rate and ecophysiology among 34 grassland and savanna species under contrasting $\mathrm{N}$ supply: a test of functional group differences. New Phytologist 157:617-631.
RIBEIRO, R.V., SOUZA, G.M., OLIVEIRA, R.F. \& MACHADO, E.C. 2005. Photosynthetic responses of tropical tree species from different successional groups under contrasting irradiance conditions. Revista Brasileira de Botânica 28:149-161.

RIDDOCH, I., LEHTO, T. \& GRACE, J. 1991. Photosynthesis of tropical tree seedlings in relation to light and nutrient supply. New Phytologist 119:137-147.

ROZENDAAL, D.M.A., HURTADO, V.H. \& POORTER, L. 2006. Plasticity in leaf traits of 38 tropical tree species in response to light; relationships with light demand and adult stature. Functional Ecology 20:207-216.

SOUZA, G.M., RIBEIRO, R.V., OLIVEIRA, R.F. \& MACHADO, E.C. 2005. Network connectance and autonomy analyses of the photosynthetic apparatus in tropical tree species from different successional groups under contrasting irradiance conditions. Revista Brasileira de Botânica 28:47-59.

STITT, M. \& HURRY, V.M. 2002. A plant for all seasons: alteration in photosynthetic carbon metabolism during cold acclimation in Arabidopsis. Current Opinion in Plant Biology 5:199-206.

STRAUSS-DEBENEDETTI, S. \& BAZZAZ, F.A. 1996. Photosynthetic characteristics of tropical trees along successional gradients. In Tropical forest plant ecophysiology (S.S. Mulkey, R.L. Chazdon \& A.P. Smith, eds.). Chapman \& Hall, New York. p.162-186.

TABARELLI, M. \& MANTOVANI, W. 1999. A regeneração de uma floresta tropical montana após corte e queima (São Paulo, Brasil). Revista Brasileira de Biologia 59:239-250.

TILMAN, D. 1997. Community invisibility, recruitment limitations, and grassland biodiversity. Ecology 78:8192.

TURNBULL, M.H. 1991. The effect of light quantity and quality during development on the photosynthetic characteristics of six Australian rain-forest tree species. Oecologia 87:110-117.

VALLADARES, F., CHICO, J.M., ARANDA, I., BALAGUER, L., DIZENGREMEL, P., MARINQUE, E. \& DREYER, E. 2002. Greater high light seedling tolerance of Quercus robur over Fagus sylvatica is linked to a greater physiological plasticity. Trees, Structure and Function 16:395-403.

VALLADARES, F., SANCHEZ-GOMEZ, D. \& ZAVALA, M.A. 2006. Quantitative estimations of phenotipic plasticity: bridging the gap between the evolutionary concept and its ecological applications. Journal of Ecology 94:1103-1116. 